Kinestetik : Jurnal Ilmiah Pendidikan Jasmani 5 (2) (2021)
Kinestetik : Jurnal Ilmiah Pendidikan Jasmani
https://ejournal.unib.ac.id/index.php/kinestetik/index
DOI : $10.33369 / j k$.v5i2.17783

\title{
IMPLEMENTATION OF PHYSICAL EDUCATION IN ELEMENTARY SCHOOL A ENTIRE MUSI RAWAS DISTRICT WITH ONLINE LEARNING SYSTEM IN THE MIDDLE OF THE COVID-19 PANDEMIC
}

Tono Sugihartono*1, Santun Sihombing ${ }^{2}$, Bayu Nirwana Sandi ${ }^{3}$

${ }^{123}$ Physical Education, Universitas Bengkulu, Bengkulu City, Indonesia

\section{Article Info}

Article History :

Received :June 2021

Revised : June 2021

Accepted : June 2021

Available online: June 2021

Keywords:

Covid-19,Implementation, Online Learning,

\begin{abstract}
This study aims to determine the Implementation of Physical Education in Elementary Schools in- Musi Rawas Regency with the Online Learning System in the Middle of the Covid-19 Pandemic. This type of research is a qualitative descriptive study. Instruments and data collection techniques using observation, interviews, questionnaires, and documentation. The subjects in this study were 30 PJOK teachers. The object of this research is the implementation of elementary school physical education in-Musi Rawas Regency. Based on all the research results that have been conducted by researchers, the results obtained according to the results of observations have a moderate category with a percentage (57.87\%), the results of the interview are in a good category with a percentage $(65 \%)$, and the results of the questionnaire have a good category with a percentage $(77.36 \%)$. So the researchers have determined that the results of the 3 research guidelines above have a good category with a percentage $(66.74 \%)$, so it can be concluded that the implementation of physical education in elementary schools throughout the Musi Rawas district with an online learning system in the midst of the Covid-19 pandemic is included in the Good category.
\end{abstract}

Corresponding address: Jl. Raden Fatah No. 100, Bengkulu City

* Corresponding email: Sugihartono@unib.ac.id
ISSN 2685-6514 (Online)

ISSN 2477-331X (Print) 


\section{INTRODUCTION}

Education has an important role in the development of human potential. In Indonesia, in general, there are two models of the education system, the first is the national education model and the local education model. The national education model means an education system in which the curriculum, assessment, supervision and to measure the nation's education level are managed, supervised by the state. Meanwhile, local education is education developed by individuals in the community, both in terms of curriculum, assessment system and even evaluation.

In education in Indonesia today, many efforts are being made in developing the potential and quality of human resources, one of which is through physical education learning. Physical education is still not taken seriously. This can be observed from the government's lack of seriousness in this subject. Whereas in developed countries the subject of physical education is one of the subjects that is the focus in order to improve and spur to live a more active life. Husdarta (2011) physical education and health is essentially an educational process that utilizes physical activity and health to produce holistic changes and individual qualities, both in terms of physical, mental, and emotional.

UUSPN No. 20 of 2003 states that learning is a process of interaction between students and educators and learning resources in a learning environment. These activities can run well if there is direct interaction between educators and teaching staff in order to achieve a planned teaching program. However, in the middle of the teaching and learning process, problems began to occur due to the Covid-19 pandemic.

At this time the spread of Covid-19 in Indonesia is increasingly widespread until 34 provinces have indicated this virus. The increasingly widespread spread of the virus has hampered several sectors such as the tourism, education, economic, social and cultural sectors. Education is one of the sectors experiencing delays in implementation due to this epidemic. Starting from the elementary school level to the tertiary level, they experienced the same impact. Various ways are taken by the government so that the learning process does not stop, namely by implementing an online learning system.

The Covid-19 pandemic has changed the learning system in every school, both at the elementary school to college level. Although the system has been implemented in schools to universities, the problem of implementing the online learning system is still experiencing obstacles.

According to the observations that the author has done at SDN. Ngadirejo, Tugumulyo District, Musi Rawas Regency, from the results of observations that have been carried out through the interview method by a physical education teacher, Mr. Mardiya, S.Pd. The application of the online learning system is considered less helpful in the implementation of teaching and learning.

Based on the problems above, the authors try to examine how the implementation or implementation of physical education that occurs at the elementary school level. Therefore, in this study the author took the title "Implementation of Physical Education in Elementary Schools in Musi Rawas Regency with an Online Learning System in the Middle of the Covid-19 Pandemic".

\section{METHODS}

This type of research uses a qualitative descriptive method, which is a research method carried out with the main aim of making an objective description or description of a situation that has to do with the problem being studied, namely the implementation of physical education teachers on online learning during the pandemic. Covid-19 in elementary schools in Musi Rawas district. The research approach used in this study uses a cross sectional approach, observation, or data collection, (Praskoabdullah, 2016).

That is, each research subject was only observed once and measurements were made on the status of the subject variable at the time of examination. Collecting data in this study using a questionnaire technique 
conducted by researchers to all physical education teachers and elementary school students in Musi Rawas Regency.

The location of the research was carried out in all elementary schools in Musi Rawas Regency. This research was conducted on 27 July - 27 August in all public elementary schools in Musi Rawas Regency.

The subjects in this study were 30 physical education teachers in 30 public elementary schools throughout Musi Rawas Regency. The object of this research is the implementation of physical education in elementary schools in Musi Rawas Regency.

According to Sugiyono (2016) data collection can be done in various settings and in various ways. When viewed from the source of the data, the data collection can use primary sources and secondary sources. Primary sources are data sources that directly provide data to data collectors. Secondary sources are sources that do not directly provide data to data collectors, for example through other people or through documents. Furthermore, in terms of data collection methods or techniques, data collection techniques can be carried out by observation, interviews, questionnaires, documentation and a combination of the four.

According to Ahmadi (2014) in qualitative research, research instruments are humans, namely the researchers themselves or other people who are trained. Data collection instruments in this study were carried out using various techniques, namely observation guidelines, interview guidelines, questionnaire guidelines, and documentation guidelines.

Data analysis techniques are very important in research because data analysis can provide useful meanings in solving research problems. The research technique according to the model of Miles and Huberman (1984) in (Sugiyono, 2006), suggests that activities in qualitative data analysis are carried out interactively and take place continuously until complete, so that the data is saturated. Activities in data analysis are data reduction, data display, and conclusion The data collection technique in this study using descriptive analysis is used to analyze data by describing or describing the data that has been collected as it is without intending to make conclusions that apply to the public or generalizations. Furthermore, it can be interpreted as a discussion of the problems posed in the form of percentages.

According to Sudjono (2005) the formula for calculating the relative frequency (percentage) is as follows

$$
\begin{aligned}
& \text { Relative Frequency Formula } \\
& \qquad \mathrm{P}=\mathrm{X} 100 \% \frac{\mathrm{F}}{\mathrm{N}}
\end{aligned}
$$

Information :

$\mathrm{P} \quad$ : percentage number

$\mathrm{F} \quad$ : number of frequencies

$\mathrm{N}$ : number of subjects (respondents)

Furthermore, data processing will be assisted with a Microsoft Excel computer program to make it easier, then the analysis process is carried out by categorizing. The categorization uses the mean and standard deviation. According to Azwar (2010) to determine the score criteria using the Norm Reference Research (PAN) on a scale that can be seen in the following table.

Table 1. Categorization Norms

\begin{tabular}{ll}
\hline Percentage & Category \\
\hline $81 \%-100 \%$ & Very good \\
\hline $61 \%-80 \%$ & Well \\
\hline $41 \%-60 \%$ & Currently \\
\hline $21 \%-40 \%$ & Not good \\
\hline $0 \%-20 \%$ & Not very good
\end{tabular}

(Azwar, 2010: 43)

\section{RESULTS}

\section{A. Observation}

Based on the results of the analysis of the observation sheet, it can be seen that the implementation of physical education in elementary schools throughout the Musi Rawas district with an online learning system 
in the midst of the covid-19 pandemic, observations with opening indicators obtained percentages $(66.66 \%)$, content indicators with percentages $(59,16 \%)$, and closing indicators $(47.77 \%)$. So it can be concluded that the results of the analysis of the observation sheet on the implementation of physical education in elementary schools throughout the Musi Rawas district with an online learning system in the midst of the covid-19 pandemic has a medium category with a percentage $(57.87 \%)$. Of the three indicators above, the lowest percentage is the closing indicator with a percentage $(47.77 \%)$ and the highest percentage is the opening indicator with a percentage $(66.66 \%)$.

\section{B. Interview}

Based on the results of interview analysis, it can be seen that the implementation of physical education in elementary schools throughout the Musi Rawas district with an online learning system in the midst of the covid-19 pandemic, interviews with cognitive indicators obtained a percentage $(88.88 \%)$, affective indicators with a percentage (68 $.33 \%)$, and psychomotor indicators $(37.77 \%)$. So it can be concluded that the results of the interview analysis of the implementation of physical education in elementary schools throughout Musi Rawas district with an online learning system in the midst of the covid-19 pandemic have a good category with a percentage (65\%). Of the three indicators above, the lowest percentage is the psychomotor indicator with a percentage $(37.77,33 \%)$ and the highest percentage is a cognitive indicator with a percentage $(88.88 \%)$.

\section{Questionnaire}

Based on the results of the questionnaire analysis, it can be seen that the implementation of physical education in elementary schools throughout the Musi Rawas district with an online learning system in the midst of the covid-19 pandemic with indicators of professional competence $(82.37 \%)$, indicators of competence in the learning process with a percentage $(77.71 \%)$, indicators of facilities and infrastructure
(82.66\%), indicators of learning inhibition competencies $(77.14 \%)$, indicators of learning support competencies $(73 \%)$, and indicators of competence in learning objectives with a percentage $(71.33 \%)$. So it can be concluded that the implementation of physical education in elementary schools throughout Musi Rawas Regency with an online learning system in the midst of the COVID-19 pandemic has a good category with a percentage $(77.36 \%)$. Of the six items above, the lowest percentage with learning objectives is the percentage ( 71 .

\section{DISCUSSION}

Based on the results of the analysis of the observation sheet, it can be seen that the implementation of physical education in elementary schools throughout the Musi Rawas district with an online learning system in the midst of the covid-19 pandemic, observations with opening indicators obtained percentages $(66.66 \%)$, content indicators with percentages $(59,16 \%)$, and closing indicators (47.77\%). So it can be concluded that the results of the analysis of the observation sheet on the implementation of physical education in elementary schools throughout the Musi Rawas district with an online learning system in the midst of the covid-19 pandemic has a medium category with a percentage $(57.87 \%)$.

According to Ahmadi (2014:161) the purpose of observation is to describe the setting being observed, the activities that occur in the background, the people who participate in the activities, the meaning of the setting, the activities and their participation in the results of the observations in the form of activities, certain events, events, objects, conditions or atmosphere in this case to find out about the implementation of physical education in elementary schools throughout Musi Rawas Regency.

Esterberg (in Sugiyono, 2016:72) describes as follows: "A meeting of two people to exchange information and ideas through question and responses, resulting in communication and joint construction of meaning about a particular topic". An interview is a meeting of two people to exchange information and ideas through 
question and answer, so that meaning can be constructed in a particular topic. The technique used in this research is in-depth interviews, namely interviews by asking several questions in depth about the implementation of physical education in elementary schools throughout Musi Rawas Regency.

Based on the results of the interview analysis that has been carried out, it can be seen that the implementation of physical education in elementary schools throughout the Musi Rawas district with an online learning system in the midst of the covid-19 pandemic, interviews with cognitive indicators obtained a percentage $(88.88 \%)$, affective indicators with percentage $(68.33 \%)$, and psychomotor indicators $(37.77 \%)$. So it can be concluded that the results of the interview analysis of the implementation of physical education in elementary schools throughout Musi Rawas district with an online learning system in the midst of the covid-19 pandemic have a good category with a percentage $(65 \%)$. Of the three indicators above, the lowest percentage is the psychomotor indicator with a percentage $(37.77 \%)$ and the highest percentage is a cognitive indicator with a percentage $(88.88 \%)$.

Based on the results of the questionnaire, it shows that the implementation of physical education in elementary schools throughout the Musi Rawas district with an online learning system in the midst of the COVID-19 pandemic is $77.36 \%$ which is included in the good category.

The results of the study showed that the discussion regarding the implementation of physical education in elementary schools throughout the Musi Rawas district with an online learning system in the midst of the covid-19 pandemic, the results of a questionnaire consisting of 6 categories of indicators regarding the learning process of physical education teachers in the school obtained data with percentage (77.36\%).

According to Irwanto (2020: 191) Online learning is learning that utilizes multimedia technology, videos, virtual classes, animated online texts, voice messages, emails, conference calls, and online streaming videos. done for free or paid. This is done to avoid direct contact between educators and students where conventional or face-toface learning systems can expand the spread of the Covid-19 virus, the learning process is going well.

Based on all the results of research that has been carried out by researchers, the results obtained according to observations have a medium category with a percentage $(57.87 \%)$, the interview results have a good category with a percentage $(65 \%)$, and the results of the questionnaire have a good category with a percentage $(77.36 \%$. So the researchers have determined the results of the 3 research guidelines above have a good category with a percentage $(66.74 \%)$, so it can be concluded that the implementation of physical education in elementary schools throughout the Musi Rawas district with an online learning system in the midst of the covid-19 pandemic is included in the Good category.

\section{CONCLUSIONS}

Based on all the results of research that has been carried out by researchers, the results obtained according to observations have a medium category with a percentage $(57.87 \%)$, the interview results have a good category with a percentage $(65 \%)$, and the results of the questionnaire have a good category with a percentage $(77.36 \%$. So the researchers have determined the results of the 3 research guidelines above have a good category with a percentage $(66.74 \%)$, so it can be concluded that the implementation of physical education in elementary schools throughout the Musi Rawas district with an online learning system in the midst of the covid-19 pandemic is included in the Good category.

\section{SUGGESTION}

Based on the conclusions of the study, suggestions that can be submitted are:

1. Physical education teachers must adapt to students' abilities in online physical education learning, learning carried out from home must 
certainly be able to improve students' fitness levels, motor skills, and values that include cognitive, effective and social aspects.

2. Physical education teachers are expected to be able to provide motivation, input and occasionally conduct evaluations to find out students are doing online learning.

3. Physical education teachers are expected to make learning forms through videos that can be used to demonstrate movements in the psychomotor realm, and students are also expected to be able to imitate the movements that have been given by physical education teachers and carried out from home.

4. Physical education teachers are expected to master IT more so that learning becomes more fun, effective and modern.

5. Teachers are expected during the implementation of online learning to be more selective in giving assignments to students, so that all aspects consisting of cognitive, affective, and psychomotor aspects can be achieved properly.

\section{REFERENCES}

Achmad. (2020). Model Pembelajaran Daring Sebagai Alternatif Proses Kegiatan Belajar Pendidikan Jasmani di Tengah Pandemi Covid-19. Jurnal Pendidikan Kesehatan Rekreasi Vol.6 No.2.

Ahmadi, Ruslam. (2014). Metodologi Penelitian Kualitatif. Yogyakarta : Ar-Ruzz Media.

Anhusadar. (2020). Persepsi mahasiswa PAUD terhadap kuliah online dimasa pandemi covid-19. Journal Of Islamic Early Childhood Education Vol.3 No.1.

Husdarta. (2011). Manajemen Pendidikan Jasmani, Bandung : Alfabeta

Irwanto. (2020). Model Pembelajaran Daring Sebagai Alternatif Proses Kegiatan Belajar Pendidikan Jasmani di Tengah Pandemi Covid-19. Jurnal Pendidikan Kesehatan Rekreasi Vol.6 No.2.

Kemendikbud. (2013). Peraturan Pemerintah No 32 Tahun 2013 Tentang Perubahan Atas Peraturan Pemerintah No 19 Tahun 2005 Tentang Standar Nasional Pendidikan. Jakarta: Kementerian Pendidikan dan Kebudayaan Republik Indonesia.
Kemendikbud. (2020). Data Referensi Kementrian Pendidikan Dan Kebudayaan. Jakarta: Kemendikbud.

Mulyadi, Deddy. (2015). Study Kebijakan Publik Dan Pelayanan Publik, Bandung : Alfabeta.

Musfah, Jejen. (2012). Peningkatan Kompetensi Guru : Melalui Pelatihan dan Sumber Belajar Teori dan Praktik. Jakarta: Kencana.

Ngalim, Purwanto. (2014). Administrasi dan Supervisi Pendidikan. Bandung: PT. Remaja Rosdakarya.

Praskoabdullah. (2016). Penyuluhan Metode Audio Visual Dan Demonstrasi Terhadap Pengetahuan Menyikat Gigi Pada Anak Sekolah Dasar . Jurnal Kesehatan Gigi Vol.03 No.2.

Pujianto, D dan Insanistyo, B. (2013). Dasar-Dasar Penelitian Pendidikan Jasmani. Bengkulu. FKIP Universitas Bengkulu.

Siregar, Sofyan. (2013). Metode Penelitian Kuantitatif. Jakarta: Kencana.

Sugiyono, P. D. (2016). Metode Penelitian Kuantitatif Kualitatif Dan R\&D. Bandung: Alfabeta.

Suherman, M. (2020). Potensi Pembelajaran Pendidikan Jasmani Olahraga Dan Kesehatan (Pjok) Di Tengah Pandemi Corona Virus Disease (Covid)-19 Di Sekolah Dasar. Tadulako Journal Sport Sciences And Physical Education Vol.8 No.1

Sukardi. (2016). Metodologi Penelitian Pendidikan Kompetensi dan Praktiknya. Jakarta: PT Bumi Aksara.

Sutapa, Sari. (2020). Efektivitas Pembelajaran Jarak Jauh Dengan Daring Selama Pandemi covid-19 Mata Pelajaran Pendidikan Jasmani Olahraga dan Kesehatan. Prosiding Seminar Nasional Olahraga Vol.2 No.1.

Syahida, Agung, Bayu. (2014). Implementasi Perda Nomor 14 Tahun 2009 Tentang Pengelolaan Sampah Di Kota Tanjungpinang (Study Kasus Di Kelurahan Tanjung Unggat).

Tahir, Arifin. (2014). Kebijakan Publik Dan Transparansi Penyelenggaraan Pemerintah Daerah. Bandung: Alfabeta.

Winarko, A. (2015). Persepsi Guru PJOK Terhadap Perubahan Kurikulum 2013 Ke KTSP Pada Matapelajaran PJOK Di Sma Negeri Se-Kota Blitar. Jurnal Pendidikan Olahraga Dan Kesehatan Vol.03 No.03 